\section{EREM 76/2}

Journal of Environmental Research, Engineering and Management

Vol. 76 / No. 2 / 2020

pp. 34-42

DOI 10.5755/j01.erem.76.2.23407
The Effect of Tin Compounds on the Lipid Peroxidation Level of Russian Sturgeon Fresh and Cryopreserved Sperm

\begin{tabular}{|l|r|}
\hline Received 2019/05 & Accepted after revision 2020/06 \\
\hline Cross ef http://dx.doi.org/10.5755/j01.erem.76.2.23407 \\
\hline
\end{tabular}

\title{
The Effect of Tin
}

\section{Compounds on the Lipid Peroxidation Level of Russian Sturgeon Fresh and Cryopreserved Sperm}

\section{N. Kolyada, V. P. Osipova*}

Southern Scientific Centre RAS, 344006 Rostov-on-Don, Russia

\author{
N. T. Berberova, Yu. T. Pimenov \\ Astrakhan State Technical University, 414056 Astrakhan, Russia
}

\section{*Corresponding author: osipova_vp@mail.ru}

The effect of organotin compounds (OTs) on the accumulation of the lipid peroxidation (LPO) carbonyl by-products, which react with thiobarbituric acid (TBARS) in fresh and cryopreserved sperm of Russian sturgeon, was studied. It was found that incubation (1 hour) of Russian sturgeon sperm with OTs $\left(\mathrm{CH}_{3} \mathrm{SnCl}_{3},\left(\mathrm{CH}_{3}\right)_{2} \mathrm{SnCl}_{2}\right.$, $\left.\left(\mathrm{CH}_{3}\right)_{3} \mathrm{SnCl},\left(n-\mathrm{C}_{4} \mathrm{H}_{9}\right)_{2} \mathrm{SnCl}_{2},\left(n-\mathrm{C}_{4} \mathrm{H}_{9}\right)_{3} \mathrm{SnCl},\left(\mathrm{C}_{6} \mathrm{H}_{5}\right)_{2} \mathrm{SnCl}_{2},\left(\mathrm{C}_{6} \mathrm{H}_{5}\right)_{3} \mathrm{SnCl}\right)$ in concentration $0.1 \mathrm{mM}$ led to the promotion of the accumulation of TBARS in native semen. Dimethyl- (DMT) and diphenyltin dichlorides (DPT) exhibited the greatest promoting activity, and the LPO level of both native and cryopreserved sperm of Russian sturgeon, including those in modified Stein's cryomedium, increased in the presence of these compounds. It was found that Russian sturgeon's cryopreserved sperm had lower sensitivity to the promotion of sperm LPO by DMT and DPT compared with the native sperm. The protective effect of Stein's cryomedium decreased in the presence of the studied OTs. The results suggest that accumulation of OTs by gonad of fish is another stress factor affecting the cell productivity in the cryopreservation process.

Keywords: Russian sturgeon fresh and cryopreserved sperm, organotin compounds, lipid peroxidation, cryomedium. 


\section{Introduction}

Russian sturgeon (Acipenser gueldenstaedtii Brandt, 1833) is among those commercially precious sturgeon species in the Caspian Sea, the natural populations of which have drastically declined in the last decade. One of the most significant factors influencing the population of sturgeons in the Caspian Sea is contamination of water and sediment by various pollutants, which are disrupting for the migration and reproduction of the sturgeons (Basu and Janz, 2013).

Due to their benthic nature, sturgeons are very sensitive to contaminants (Miandare et al., 2016) including organotin compounds (OTs), which are highly toxic persistent organometallic xenobiotics in the environment. At the same time, OTs are widely used in several commercial applications. The extensive use of trisubstituted butyl and phenyl derivatives of tin as biocides in antifouling systems on ships has led to an unprecedented contamination of the marine environment at a global scale. Methyltins are probably produced by biomethylation of the commercial OTs in the environment (Bridou et al., 2018). Thus, OTs are habitual components of aquatic ecosystems. These OTs effectively accumulate in molluscs (Antizar-Ladislao, 2008), which are the preferred foodstuff of sturgeons.

Elevated levels of heavy metals and persistent organic pollutants in water, sediments, bottom organisms and some fish species (Mirnategh et al., 2018), including sturgeons of the Caspian Sea (Kajiwara et al., 2008), were considered in some studies. However, not much is known about the status of OTs contamination in the sturgeons from the Caspian Sea.

Despite the fact that since 2008 the use of tributyl tin compounds as a biocidal additive in anti-fouling coatings was prohibited in the EU due to the accumulation of these compounds by bottom sediments, they continue to enter water bodies (Chen et al., 2019). OTs can be easily absorbed into the tissues of aquatic animals with bioconcentration factors of $10^{2}-10^{4}$ (Chen et al., 2017) and are considerably persistent, including persistence in hydrobiont gonads (Hu et al., 2009). The reproductive system of aquatic organisms is the most sensitive to the toxic effects of xenobiotics. Spermatozoa, including cryopreserved sperm, are used for the ecotoxicological evaluation of aquatic environment (Fabbrocini et al., 2013). Despite the sturgeon's endangered status in the Caspian Sea, there are only a few studies dealing with relative sensitivity of sturgeons to OTs (Graceli et al., 2013). Literature data indicate the relative stability of sturgeon sperm (Siberian sturgeon and starlet) to the negative effects of such heavy metals as mercury and cadmium (Dietrich et al., 2012). It was found that at presence of the OTs the mobility of hydrobionts sperm reduced (Shim et al., 2006) and its conservation also was inferior (Li, 2001); however, this problem has not been studied in view of the tasks of cryobiology.

Drastic declines in sturgeon natural populations have led to sturgeons classifying as an endangered breed. Thus, sturgeon aquaculture has gained importance over the past years. The exposure of fish to industrial and agrochemical origin pollutant-containing water is one of the factors affecting the quality of fish sperm in aquaculture. OTs can enter fish sperm during artificial fish farming due to their accumulation in the germ cells of spawners, caught in natural water bodies polluted with toxicants (Okoro et al., 2011). Artificial fish food, used in sturgeon industrial breeding, may also contain OTs (Saïdi et al., 2013). In addition, possible leaching of dimethyl-, dibutyltin dichlorides used in aquaculture polyvinyl chlorine (PVC) and chlorinated polyvinyl chloride (CPVC) plastics used as stabilisers of polymers (Matthews, 1996) should be taken into account. Although OTs are leached out in very low concentrations, it is very probable that they accumulate in a lipid-rich sperm of fish. Taking into account that an increase of lipid peroxidation intensity (LPO) may be one of the mechanisms of a negative effect of OTs on hydrobiont sperm, the effect of organotin compounds on the LPO level in Russian sturgeon fresh and cryopreserved sperm was investigated in this study.

\section{Methods}

\section{Reagents and solutions}

Organotin compounds $\left(\mathrm{CH}_{3} \mathrm{SnCl}_{3}, \quad\left(\mathrm{CH}_{3}\right)_{2} \mathrm{SnCl}_{2}\right.$, $\left(\mathrm{CH}_{3}\right)_{3} \mathrm{SnCl},\left(n-\mathrm{C}_{4} \mathrm{H}_{9}\right)_{2} \mathrm{SnCl}_{2},\left(n-\mathrm{C}_{4} \mathrm{H}_{9}\right)_{3} \mathrm{SnCl},\left(\mathrm{C}_{6} \mathrm{H}_{5}\right)_{2} \mathrm{SnCl}_{2}$, $\left.\left(\mathrm{C}_{6} \mathrm{H}_{5}\right)_{3} \mathrm{SnCl}\right)$ and all other reagents were purchased 
from Sigma-Aldrich. In this work, the modified Stein's cryomedium (130 mM NaCl, $5 \mathrm{mM} \mathrm{KCl}, 20 \mathrm{mM} \mathrm{NaHCO}_{3}$, $5.5 \mathrm{mM}$ glucose, $12.5 \%$ egg yolk, $12.5 \%$ DMSO) (Osipova et al., 2014) was used.

\section{Sperm collection}

Russian sturgeon sperm was received from Bertyulsky, Lebyazhyi and Sergiyevsky sturgeon hatcheries of the Low Volga. Tests were carried out during the period from 2016 to 2018. Every year naturally mature fish (810 male fish, each weighing $15-18 \mathrm{~kg}(17.0 \pm 0.9 \mathrm{~kg})$, 10-12 years old) were obtained during the period of the spawning migration (from the middle of April). Spermiation in males was induced by a single injection of surfagon (Mosagrogen LTD, Russia). The dose was calculated per $1.0 \mathrm{~kg}$ of male body weight and amounted to $5.0 \mathrm{mg} / \mathrm{kg}$ at water temperature $12^{\circ} \mathrm{C}$. Sperm was collected by a catheter. Sperm samples were placed on ice and transported to the laboratory.

\section{Incubation of semen with organotins}

The $\mathrm{CH}_{3} \mathrm{SnCl}_{3},\left(\mathrm{CH}_{3}\right)_{2} \mathrm{SnCl}_{2},\left(\mathrm{CH}_{3}\right)_{3} \mathrm{SnCl},\left(n-\mathrm{C}_{4} \mathrm{H}_{9}\right)_{2} \mathrm{SnCl}_{2}$, $\left(n-\mathrm{C}_{4} \mathrm{H}_{9}\right)_{3} \mathrm{SnCl},\left(\mathrm{C}_{6} \mathrm{H}_{5}\right)_{2} \mathrm{SnCl}_{2}\left(\mathrm{C}_{6} \mathrm{H}_{5}\right)_{3} \mathrm{SnCl}$ were diluted in the sturgeon semen. The resulting mixture was incubated for $1 \mathrm{~h}$ at $5^{\circ} \mathrm{C}$.

\section{General procedure for sperm freezing and thawing}

Sperm cryopreservation was carried out according to the methods of Tsvetkova et al. (Tsvetkova et al., 1997). The diluted with the cryoprotective medium sperm was distributed in labelled $1.5 \mathrm{~mL}$ Eppendorf tubes and placed in a refrigerator for $40 \mathrm{~min}$ for equilibration (Kopeyka et al., 1981). The ratio of sperm and cryomedium was 1:1. After equilibration, deep freezing was performed in three stages in a programmable freezing box with an electronic thermometer: from $5^{\circ} \mathrm{C}$ to $-15^{\circ} \mathrm{C}$ with the rate $2-5^{\circ} \mathrm{C} / \mathrm{min}$ (freezing time $2-5 \mathrm{~min}$ ); from $-15^{\circ} \mathrm{C}$ to $-70^{\circ} \mathrm{C}$ with the rate $20-25^{\circ} \mathrm{C} / \mathrm{min}$ (freezing time about $3 \mathrm{~min}$ ); deep freezing in liquid nitrogen. Thawing of sperm was performed in a water bath during $30-40 \mathrm{~s}$ at $38-40^{\circ} \mathrm{C}$.

\section{Determination of the accumulation level of TBARS in Russian sturgeon sperm}

The intensity of sperm lipoperoxidation was assessed by the accumulation of carbonyl oxidation by-products, which react with thiobarbituric acid (TBARS), using the traditional method as described previously (Osipova et al., 2017; Polovinkina et al., 2019). The content of TBARS was expressed as nanomoles per $10^{9}$ cells. In experiments of TBARS determination before cryopreservation (without cryomedium), $1 \mathrm{~mL}$ of sperm was used. In experiments of TBARS determination with cryomedium before and after cryopreservation, the diluted sperm, the quantity of which was equivalent to $1 \mathrm{~mL}$ of undiluted sperm, was applied.

\section{a before cryopreservation without cryomedium}

To $156 \mathrm{~mL}$ of $1.2 \%$ solution of $\mathrm{KCl}$ at $0-4^{\circ} \mathrm{C}, 8 \mathrm{~mL}$ of sturgeon sperm without the addition of tin compounds (control) or with the addition of tested OTs were added. The resulting mixture was incubated for $1 \mathrm{~h}$ at $5^{\circ} \mathrm{C}$, and the $2 \mathrm{~mL}$ probes of a mixture were taken into the plastic tubes $(4 \mathrm{~mL})$ for centrifugation. $0.1 \mathrm{~mL}$ of 2.6 $\mathrm{mM}$ solution of ascorbic acid, $0.1 \mathrm{~mL}$ of $40 \mathrm{mM}$ Mohr's salt, and $1 \mathrm{~mL}$ of $40 \%$ solution trichloroacetic acid were added to each probe. The tubes were placed for $10 \mathrm{~min}$ in a water bath at $37^{\circ} \mathrm{C}$ and then were centrifuged for $10 \mathrm{~min}$ at $3,000 \mathrm{~g}$. On the next step, $2 \mathrm{~mL}$ of supernatant were transferred to clean tubes, $1 \mathrm{~mL}$ of $0.8 \%$ solution of thiobarbituric acid was added, and the tubes were placed into a boiling water bath for $10 \mathrm{~min}$ and then were cooled to the room temperature $\left(25^{\circ} \mathrm{C}\right)$. After cooling, $1.0 \mathrm{~mL}$ portions of chloroform were added to the tubes to obtain the transparent solutions and these probes were centrifuged at 3,000 $\mathrm{g}$ for $15 \mathrm{~min}$. Supernatant liquid was collected, and extinction of the probe was measured using SF-103 spectrophotometer at $532 \mathrm{~nm}$; the test probe was taken as a standard. The calculation was performed by the formula:

$X=(E \times 3 \times 3.2) /(0.156 \times 2)$

where $X(n m o l)$ is the quantity of TBARS in native sperm; $E$ is the extinction factor of the probe; $3.2 \mathrm{~mL}$ is the total volume of sperm from the tested fish; $2 \mathrm{~mL}$ is the volume of supernatant used for TBARS determination; $3 \mathrm{~mL}$ is the total volume of probes; 0.156 is the extinction factor of the $1 \mathrm{nmol}$ TBARS at $532 \mathrm{~nm}$.

The effect of organotin compounds supplements on TBARS accumulation in the sperm species diluted by the modified Stein's cryomedium was studied before cryopreservation during incubation of the compound 
at room temperature for $1 \mathrm{~h}$ and after cryopreservation for 3 days at a temperature equal to $-196^{\circ} \mathrm{C}$.

\section{b before cryopreservation and with cryomedium}

$1 \mathrm{~mL}$ of semen without the addition of tin compounds (control) or with the addition of tested OTs diluted with cryomedium (1:1) was mixed with $19.5 \mathrm{~mL}$ of cooled $1.2 \% \mathrm{KCl}$ solution. $0.1 \mathrm{~mL}$ of $2.6 \mathrm{mM}$ solution of ascorbic acid and $0.1 \mathrm{~mL}$ of $40 \mathrm{mM}$ solution of Mohr's salt, $1 \mathrm{~mL}$ of $40 \%$ solution of trichloroacetic acid were added to $2 \mathrm{~mL}$ of the mixture. The subsequent procedure was identical to the described in the previous case.

\section{c after cryopreservation with cryomedium}

The sperm without the addition of OTs (control) or with the addition of the tested organotin compound at $0.1 \mathrm{mM}$ concentration diluted by cryomedium (1:1) was frozen and thawed as described in General procedure for sperm freezing and thawing. After thawing, the sperm $(2 \mathrm{~mL})$ in a quantity equivalent to $1 \mathrm{~mL}$ of undiluted sperm was placed in tubes, then $0.1 \mathrm{~mL}$ of $2.6 \mathrm{mM}$ solution of ascorbic acid, $0.1 \mathrm{~mL}$ of $40 \mathrm{mM}$ solution of Mohr's salt, and $1 \mathrm{~mL}$ of $40 \%$ solution of trichloroacetic acid were added. The subsequent procedure was identical to the described in the section $a$.

\section{Statistical analysis}

The statistical analysis was performed using Statistica for Windows, Version 9.0 (StatSoft, Inc.), and the data were presented as mean \pm SD. All experiments were repeated three times. TBARS concentrations in experiment were analysed using an unpaired Student's $t$ test. Statistical significance was set up at $p<0.05$.

\section{Results and Discussion}

Fish spermatozoa are sensitive to damage by ROS, since they contain large amounts of highly unsaturated fatty acids - substrates for reactive oxygen species (ROS), but possess limited endogenous antioxidant protection (Poli et al., 2004). In spermatozoa, ROS are generated endogenously as a by-product of normal aerobic metabolism, but they may also arise from reactions with exogenous sources, such as environmental pollutants which can both depress the antioxidants capacity to remove oxyradicals or enhance the intracellular ROS formation (Regoli and Giuliani, 2014). LPO is a biomarker of oxidative stress. The results of $\mathrm{Li}$ et al. (2010b) suggested that LPO could be a more sensitive indicator for evaluating oxidative stress of fish spermatozoa compared with protein oxidation.

In the present work, it was found that incubation (1 hour) of Russian sturgeons sperm with OTs $\left(\mathrm{CH}_{3} \mathrm{SnCl}_{3}\right.$, $\left(\mathrm{CH}_{3}\right)_{2} \mathrm{SnCl}_{2}, \quad\left(\mathrm{CH}_{3}\right)_{3} \mathrm{SnCl}, \quad\left(n-\mathrm{C}_{4} \mathrm{H}_{9}\right)_{2} \mathrm{SnCl}_{2}, \quad\left(n-\mathrm{C}_{4} \mathrm{H}_{9}\right)_{3} \mathrm{SnCl}$, $\left.\left(\mathrm{C}_{6} \mathrm{H}_{5}\right)_{2} \mathrm{SnCl}_{2},\left(\mathrm{C}_{6} \mathrm{H}_{5}\right)_{3} \mathrm{SnCl}\right)$ in $0.1 \mathrm{mM}$ concentration led to the promotion of TBARS accumulation in native semen (Fig. 1). The promotion effect of OTs upon oxidation of oleic ((Z)-9-octadecenoic) acid (Petrosyan et al., 2002), sturgeon liver lipids (Antonova et al., 2008), lipids of fish feed (Osipova et al., 2017) by $\mathrm{O}_{2}$ has been previously found. Most of the carbonyl by-products derived from lipid peroxidation were toxic, since they could easily diffuse through membranes and could covalently modify important biomolecules far from their unmodified state (Negre-Salvayre et al., 2008).

The promotion of the fish sperm LPO may be caused by the fact that the interaction of OTs with the first comparatively stable products of $\mathrm{LPO}\left(\mathrm{ROOH}, \mathrm{R}^{\prime} \mathrm{OOR}\right)$ breaks the $\mathrm{Sn}-\mathrm{C}$ bond (Davies, 1997) and active alkyl radicals formed (Petrosyan et al., 2002). It was shown that in the case of $\left(n-\mathrm{C}_{4} \mathrm{H}_{9}\right)_{3} \mathrm{SnCl}$ direct chemical combination of organometallic xenobiotics with the first ROS, i.e., superoxide, which was mainly generated via autoxidation reactions or oxygen-dependent enzymatic reactions in aerobic cell, radicals also could form (Rivera et al., 1992).

The production of ROS in the presence of $\left(n-\mathrm{C}_{4} \mathrm{H}_{9}\right)_{2} \mathrm{SnCl}_{2}$ and $\left(\mathrm{C}_{6} \mathrm{H}_{5}\right)_{3} \mathrm{SnCl}$ has been reported (Chantong et al., 2014; De Castro et al., 2018). Literature data indicate that the activity of the antioxidant enzyme superoxide dismutase decreased under the action of $\left(n-\mathrm{C}_{4} \mathrm{H}_{9}\right)_{2} \mathrm{SnCl}_{2}$ (Weber et al., 1995). It should be also taken into account that sperm is particularly rich in mitochondria, which may predispose these cells to enhanced effects of OTs, because the mitochondria is the major cellular location for ROS generation upon stress (Doherty and Irwi, 2011). According to the data obtained in this work, the degree of promotion of sperm LPO by toxicants decreases in the row:

$\left(\mathrm{C}_{6} \mathrm{H}_{5}\right)_{2} \mathrm{SnCl}_{2}>\left(\mathrm{CH}_{3}\right)_{2} \mathrm{SnCl}_{2}>\left(\mathrm{n}-\mathrm{C}_{4} \mathrm{H}_{9}\right)_{2} \mathrm{SnCl}_{2}>\left(\mathrm{CH}_{3}\right)_{3} \mathrm{SnCl}>$ $\mathrm{CH}_{3} \mathrm{SnCl}_{3}>\left(\mathrm{C}_{6} \mathrm{H}_{5}\right)_{3} \mathrm{SnCl}>\left(\mathrm{n}-\mathrm{C}_{4} \mathrm{H}_{9}\right)_{3} \mathrm{SnCl}$ 
Fig. 1. The effects of $1 \mathrm{~h}$ exposure of Russian sturgeon fresh sperm to organotins on TBARS level in sperm in vitro

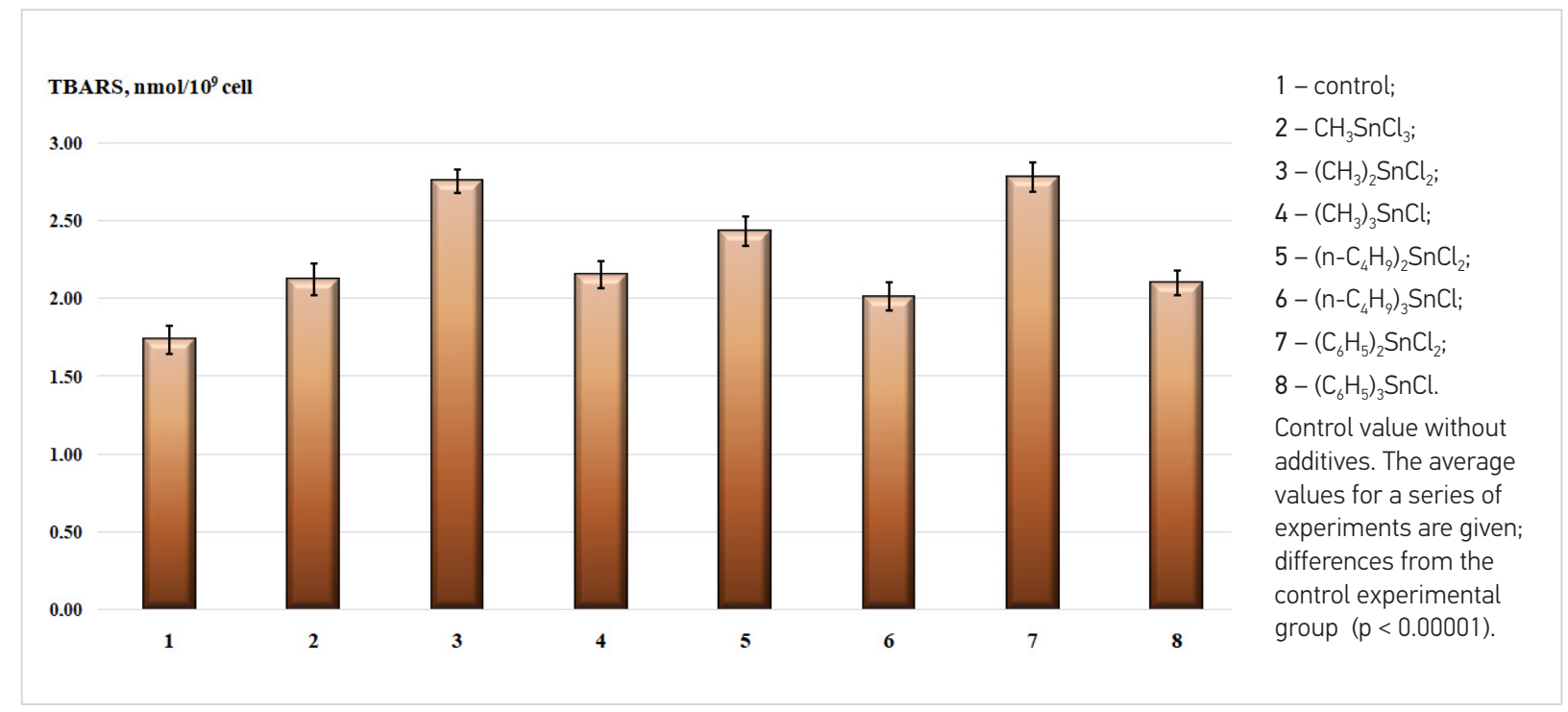

Different levels of LPO of sturgeon sperm in the presence of OTs can be associated with different capacity of germ cells to accumulate toxicants. It is known, that Chinese sturgeons have a greater capacity to accumulate $\left(\mathrm{C}_{6} \mathrm{H}_{5}\right)_{3} \mathrm{SnCl}$ relative to $\left(n-\mathrm{C}_{4} \mathrm{H}_{9}\right)_{3} \mathrm{SnCl}$ than other fish species (Hu et al., 2009).

According to the data obtained, the degree of LPO promotion in Russian sturgeon sperm in the presence of $\left(n-\mathrm{C}_{4} \mathrm{H}_{9}\right)_{3} \mathrm{SnCl}$, one of the most toxic xenobiotics in the natural waters, is lower than in the presence of $\left(n-\mathrm{C}_{4} \mathrm{H}_{9}\right)_{2} \mathrm{SnCl}_{2}$. It has been reported that $\left(n-\mathrm{C}_{4} \mathrm{H}_{9}\right)_{3} \mathrm{SnCl}$, $\left(\mathrm{C}_{6} \mathrm{H}_{5}\right)_{3} \mathrm{SnCl}$ had a high complex toxic effect on molluscs, and even at OTs concentrations in water as low as $1.0 \mathrm{ng} / \mathrm{L}$, it could produce endocrine disrupting effects, inducing imposex in female molluscs (de Araújo et al., 2018).

$\left(n-\mathrm{C}_{4} \mathrm{H}_{9}\right)_{2} \mathrm{SnCl}_{2}$ is a metabolite of $\left(n-\mathrm{C}_{4} \mathrm{H}_{9}\right)_{3} \mathrm{SnCl}$; thus, it is commonly found in tissue after exposure to $\left(n-\mathrm{C}_{4} \mathrm{H}_{9}\right)_{3} \mathrm{SnCl}$. This compound is used as a biocide to treat chickens for tapeworm and, since it is used in PVC production, it will leach into aquatic systems from pipes made of this plastic (Cima et al., 2003). It is considered that $\left(n-\mathrm{C}_{4} \mathrm{H}_{9}\right)_{2} \mathrm{SnCl}_{2}$ has low toxicity to aquatic organisms. The maximum permissible concentration (MPC) of this fishery waters pollutant is $1.0 \mu \mathrm{g} / \mathrm{L}$, which is 100 times higher than for
$\left(n-\mathrm{C}_{4} \mathrm{H}_{9}\right)_{3} \mathrm{SnCl}$ (The list of fish-farm standards, 1999). According to the results of our study, $\left(n-\mathrm{C}_{4} \mathrm{H}_{9}\right)_{2} \mathrm{SnCl}_{2}$ has a significant impact on the processes of LPO in Russian sturgeon sperm, increasing the level of accumulation of secondary products of the LPO in sperm by $41 \%$. Thus, the studies carried out in this work, as well as published data on the more significant toxic effects of dibutyltin dichloride on the immune system of fish compared with the effect of $\left(n-\mathrm{C}_{4} \mathrm{H}_{9}\right)_{3} \mathrm{SnCl}(\mathrm{O}$ 'Halloran et al., 1998), indicate that potential toxicity of $\left(n-\mathrm{C}_{4} \mathrm{H}_{9}\right)_{2} \mathrm{SnCl}_{2}$ should be re-evaluated.

The highest promoting activity has been found for dimethyl- (DMT) and diphenyltin (DPT) dichlorides, disubstituted OTs, which, presumably, are the most common organic derivatives of tin in biota, because they are formed during dealkylation of OTs and can also accumulate in tissues with a high level of metabolic processes and increased lipid content (Harino et al., 2007). DPT is a metabolite of $\left(\mathrm{C}_{6} \mathrm{H}_{5}\right)_{3} \mathrm{SnCl}$, which, like $\left(n-\mathrm{C}_{4} \mathrm{H}_{9}\right)_{3} \mathrm{SnCl}$, is used in antifouling paints. Direct proportionality between the concentration of toxicant DPT and the level of TBARS in semen was found (Fig. 2).

Cryopreservation conditions may also cause an oxidative stress, since sperm is exposed to cold shock and atmospheric oxygen during cryopreservation, which increases its susceptibility to lipid peroxidation 
Fig. 2. Effect of various concentrations of DPT on the level of TBARS in Russian sturgeon native sperm

TBARS, $\mathrm{nmol} / 10^{9}$ cell

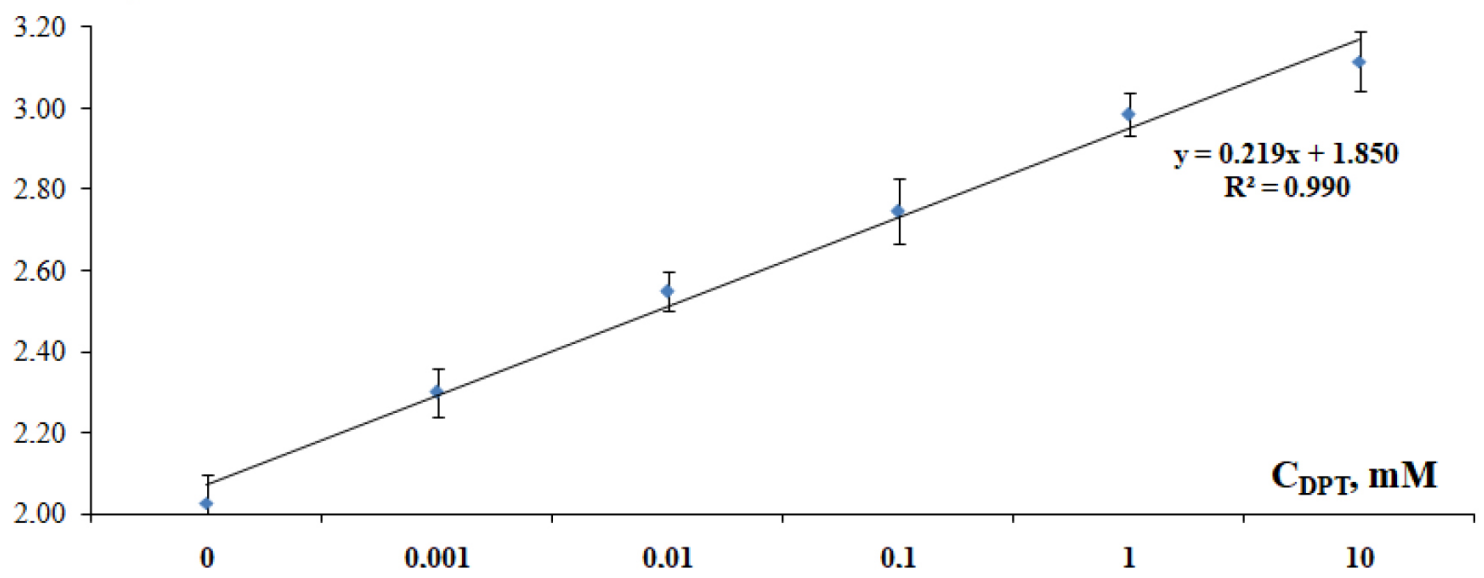

resulting from greater production of ROS ( $\mathrm{Li}$ et al., 2010a). Although low concentrations of ROS play an important role in sperm physiology (Bansal and Bilaspuri, 2011), high concentrations of ROS cause sperm pathology (Gazo, 2013). LPO is the important factor for the evaluation of sperm quality (Cabrita et al., 2014).

The effect of incubating sperm with toxicants (DMT, DPT) on the level of TBARS in defrosted semen after deep freezing was studied. In order to assess the effect of the cryomedium on the promotion of sperm LPO by tin compounds, experiments were carried out without the addition of a cryomedium and in the presence of modified Stein's cryomedium. We previously carried out research on the impact of the cryomedium composition on the level of LPO of Russian sturgeon sperm at different stages of cryopreservation and it was found that the speed of LPO of the sperm reduced at all stages of cryopreservation, which was more efficient in the modified cryomedium (Osipova et al., 2016).

In our study, the level of TBARS in control increased significantly after 3 days of sperm storage (Table 1), which is in good agreement with literature data (Shaliutina et al., 2013).

The present work demonstrated that DMT and DPT $(0.1 \mathrm{mM})$ veraciously increased the level of the LPO
Table 1. Effect of the DMT and DPT on the TBARS level (nmol/10 sperm) in Russian sturgeon sperm without and in the presence of the modified Stein's medium before and after cryopreservation

\begin{tabular}{l|c|c}
\hline & $\begin{array}{c}\text { Before } \\
\text { cryopreservation }\end{array}$ & $\begin{array}{c}\text { After } \\
\text { cryopreservation }\end{array}$ \\
\hline Control & $1.50 \pm 0.08$ & $2.03 \pm 0.08^{\star}$ \\
\hline Cryomedium & $1.08 \pm 0.07^{\mathrm{b}}$ & $1.24 \pm 0.08^{\mathrm{a}}$ \\
\hline DMT + cryomedium & $1.63 \pm 0.08^{\star \mathrm{b}}$ & $2.12 \pm 0.07^{\star \mathrm{c}}$ \\
\hline DMT & $2.03 \pm 0.08^{* * *}$ & $2.42 \pm 0.08^{\star * *+}$ \\
\hline DPT + cryomedium & $2.25 \pm 0.07^{\star \mathrm{b}}$ & $2.55 \pm 0.08^{\star \mathrm{d}}$ \\
\hline DPT & $2.48 \pm 0.03^{\star}$ & $2.58 \pm 0.07^{\star *}$ \\
\hline
\end{tabular}

Control value without additives. The average values for a series of experiments are given.

- Differences from the control experiment group before cryopreservation $(p<0.0001)$. Differences from the control experiment group * $(p<0.00001)$;

$*(p<0.00005) ; " *(p<0.0001) ;$

$* * * * 0.0005)$.

Differences from the control experiment group without cryomedium ${ }^{a}(p<0.00001) ;{ }^{b}(p<0.0005) ;{ }^{c}(p<0.005) .{ }^{d}$ Differences from the control experiment group (DPT after cryopreservation) $(p>0.05)$. The values are expressed as mean $\pm S D$. 
derived carbonyl by-products, which react with thiobarbituric acid, in frozen/thawed sperm of Russian sturgeon after prior incubation of the fresh semen in these OTs for $1 \mathrm{~h}(\mathrm{p}<0.005)$. TBARS levels of frozen/ thawed Russian sturgeon sperm would be affected 1 $h$ after the aerobic exposure of fresh semen to DMT and DPT, which indicates a decrease in the sensitivity of Russian sturgeon cryopreserved sperm to the promotion of LPO under the studied disubstituted OTs, especially DPT; therefore this indicator cannot be used as a spermiotoxicity test.

A statistically significant increase in the level of TBARS was found both in the control experiments and in the presence of DMT and DPT in comparison with the native sperm. In the control experiment without Stein's cryomedium and xenobiotics after cryopreservation, the level of LPO increased by $35 \%(p<0.0001)$, while in the presence of DMT and DPT, it increased by $20 \%$ $(p<0.00001)$ and $4 \%(p<0.01)$, respectively, compared with the experiment before cryopreservation. Comparison with the level of TBARS in the control experiment indicates the preservation of the promoting activity of tin compounds in cryopreserved semen. In the presence of DPT or DMT, the level of TBARS in defrosting sperm veraciously increases by $27 \%(p<0.00001)$ and $19 \%$ ( $p<0.00001)$, respectively, relative to control after cryopreservation without cryomedium.

In the control experiment without a toxicant, as well as in the presence of DMT and DPT, the addition of

\section{Acknowledgements}

This work was financially supported by the Russian Foundation for Basic Research (Project No. 19-0300006 , experiments with native sperm of Russian sturgeon) and the Ministry of Science and Higher

\section{References}

Antizar-Ladislao B. (2008) Environmental levels, toxicity and human exposure to tributyltin (TBT)-contaminated marine environment - a review. Environment International 34: 292-308. https://doi.org/10.1016/j.envint.2007.09.005 cryomedium to native sperm led to a decrease in TBARS by $28 \%(p<0.00001), 20 \%(p<0.00001)$ and $10 \%(p<0.00001)$, respectively. Thus, in the presence of toxicants, the protective effect of Stein's cryomedium is reduced, which, presumably, can be explained by the fact that DMT and DPT can interact with the components of the cryomedium used, for example, with DMSO (the latter is widely used, in particular, in operations with sturgeon sperm). DMSO can capture hydroxyl radical, which has the most injuring effect on the membranes of sperm cells.

With the addition of cryomedium, the level of TBARS in semen defrosted after freezing was significantly reduced in the experiment where no toxicants were added, as well as in the presence of DMT, by $39 \%$ $(p<0.00001)$ and $13 \%(p<0.005)$, respectively. The decrease in the level of secondary products of LPO of defrosted sperm with the addition of cryomedium in the presence of DPT was doubtful $(p>0.05)$.

\section{Conclusions}

Our results suggest that the accumulation of OTs by gonad of fish is the stress factor affecting the cells in the process of cryopreservation. Organotins can induce oxidative stress in sturgeon sperm in vitro, which may decrease the quality of gametes, which in turn may affect fertilisation success.

Education of the Russian Federation (within the framework of State Assignment, Project No. 01201354245 , experiments with frozen/thawed sperm of Russian sturgeon).

Antonova N., Kolyada M., Osipova V., et al. (2008) Study of the Antioxidant Properties of Phosphorylated Phenols. Doklady Chemistry 419: 342-344. https://doi.org/10.1134/ S0012500808030051 
Bansal A. and Bilaspuri G. (2011) Impacts of oxidative stress and antioxidants on semen functions. Veterinary Medicine International 2011 : 1-7. https://doi.org/10.4061/2011/686137

Basu N. and Janz D. (2013) Organometal(loid)s. Organic Chemical Toxicology of Fishes 141-194. https://doi.org/10.1016/ B978-0-12-398254-4.00003-0

Bridou R., Rodriguez-Gonzalez P., Stoichev T., et al. (2018) Methylation and dealkykation of tin compounds by sulfate and nitrate-reducing bacteria. Chemosphere 208: 871-879. https:// doi.org/10.1016/j.chemosphere.2018.06.030

Cabrita E., Martínez-Páramo S., Gavaia P., et al. (2014) Factors enhancing fish sperm quality and emerging tools for sperm analysis. Aquaculture 432: 389-401.https://doi.org/10.1016/j. aquaculture.2014.04.034

Chantong B., KratschmarD., Lister A., et al. (2014) Dibutyltin promotes oxidative stress and increases inflammatory mediators in BV-2 microglia cells. Toxicology Letters 230(2): 177-187. https://doi.org/10.1016/j.toxlet.2014.03.001

Chen C., Chen L., Huang Q., et al. (2019) Organotin contamination in commercial and wild oysters from China: Increasing occurrence of triphenyltin. Science of the Total Environment 650: 2527-2534. https://doi.org/10.1016/j.scitotenv.2018.09.310

Chen Z., Chen L., Chen C., et al. (2017) Organotin contamination in sediments and aquatic organisms from the Yangtze Estuary and adjacent marine environments. Environmental Engineering Science 34: 227-235. https://doi.org/10.1089/ees.2016.0370

Cima F. Tin: Environmental Pollution and Health Effects. In: Encyclopedia of Environmental Health, 2nd Edition. https://doi. org/10.1016/B978-0-12-409548-9.11198-4

Davies A. (1997) Organotin Chemistry, VCH, Verlagsgesellschaft, Weinheim, $327 \mathrm{p}$.

De Araújo J., Podratz P., Merlo E., et al. (2018) Organotin exposure and vertebrate reproduction: a review. Frontiers in Endocrinology 9: 64. https://doi.org/10.3389/fendo.2018.00064

Dietrich1 G., Ciereszko1 A., Kowalski1 R., et al. (2012) Motility and fertilizing capacity of frozen/thawed sperm of Siberian sturgeon after a short-time exposure of fresh semen to mercury and cadmium. Journal of Applied Ichthyology 28: 973-977. https://doi.org/10.1111/jai.12062

Doherty J. and Irwin W. (2011) Organotins (tributyltin and triphenyltin). Reproductive and Developmental Toxicology 657-672. https://doi.org/10.1016/B978-0-12-382032-7.10049-9

Fabbrocini A., D‘Adamo R., Del Prete F., et al. (2013) Motility of cryopreserved spermatozoa for the ecotoxicological evaluation of aquatic environments. Chemistry and Ecology 29 (7): 660667. https://doi.org/10.1080/02757540.2013.810723
Gazo I., Linhartova P., Shaliutina A., et al. (2013) Influence of environmentally relevant concentrations of vinclozolin on quality, DNA integrity, and antioxidant responses of sterlet Acipenser ruthenus spermatozoa. Chemico-biological interactions 203: 377-385. https://doi.org/10.1016/j.cbi.2013.01.004

Graceli J., Sena G., Lopes P., et al. (2013) Organotins: a review of their reproductive toxicity, biochemistry, and environmental fate. Reproductive Toxicology 36: 40-52. https://doi.org/10.1016/j.reprotox.2012.11.008

Harino H., Ohji M., Wattayakorn G., et al. (2007) Accumulation of Organotin Compounds in Tissues and Organs of Stranded Whales Along the Coasts of Thailand Arch. Environmental Contamination and Toxicology 53: 119-125. https://doi.org/10.1007/ s00244-006-0128-x

Hu J., Zhang Z., Wei Q., et al. (2009) Malformations of the endangered Chinese sturgeon, Acipenser sinensis, and its causal agent. Proceedings of the National Academy of Sciences 106(23): 93399344. www.pnas.orgcgidoi10.1073pnas.0809434106. https://doi. org/10.1073/pnas.0809434106

Kajiwara N., Watanabe M., Wilson S., et al. (2008) Persistent organic pollutants (POPs) in Caspian seals of unusual mortality event during 2000 and 2001. Environmental Pollution 152: 431 442. https://doi.org/10.1016/j.envpol.2007.06.075

Kopeika E. F., Belous A. M. and Pushkar N. C. (1981) Криоконсервация спермы рыб. Криоконсервация клеточных суспензий (Cryoconservation of Fish Sperm, Cryoconservation of Cells' Suspension). Киев: Изд-во «Наукова думка», 204-216.

Li P., Li Z. H., Dzyuba B., et al. (2010a) Evaluating the impacts of osmotic and oxidative stress on common carp (Cyprinus carpio, L.) sperm caused by cryopreservation techniques. Biology of Reproduction 83: 852-858. https://doi.org/10.1095/biolreprod. 110.085852

Li S. (2001) A Study on Biodiversity and Its Conservation of Major Fishes in the Yangtze River, Shanghai, China, Shanghai Scientific and Technical Publishers, p 8.

Li Z., Li P., Dziuba B., et al. (2010b) Influence of environmental related concentrations of heavy metals on motility parameters and antioxidant responses in sturgeon sperm. Chemico-biological interactions 188: 473-477. https://doi.org/10.1016/j. cbi.2010.09.005

Matthews G. (1996) PVC: Production, Properties and Uses. The Institute of Materials, England, London, 587 p.

Methods in Reproductive Aquaculture: Marine and Freshwater Species (Marine Biology) Cabrita E., Robles V. and Herr' aez P. (Eds), Section V, CRC Press, Taylor \& Francis Group, Boca Raton, FL, USA, $574 \mathrm{p}$. 
Miandare H., Niknejad M., Shabani A., et al. (2016) Exposure of Persian sturgeon (Acipenser persicus) to cadmium results in biochemical, histological and transcriptional alterations. Comparative Biochemistry and Physiology, Part C 181-182: 1-8. https://doi.org/10.1016/j.cbpc.2015.12.004

Mirnategh S. (2018) Seawater, Sediment and Fish Tissue Heavy Metal Assessment in Southern Coast of Caspian Sea. International Journal of Pharmaceutical Research \&Allied Sciences 7(3):116-125. Available at: online www.ijpras.com.

Negre-Salvayre A., Coatrieux C., Ingueneau C., et al. (2008) Advanced lipid peroxidation end products in oxidative damage to proteins. Potential role in diseases and therapeutic prospects for the inhibitors. British Journal of Pharmacology 153(1): 6-20. https://doi.org/10.3109/10715762.2010.498478

O' Halloran K., Ahokas S. and Wright P. (1998) Response of fish immune cells to in vitro organotin exposures. Aquatic Toxicology 40: 141-156. https://doi.org/10.1016/S0166-445X(97)00054-4

Okoro Ch., Fatoki O., Adekola F., et al. (2011) Sources environmental levels and toxicity of organotin in marine environment: a review. Asian Journal of Chemistry 23(2): 473-482. http://hdl. handle.net/11189/3649.

Osipova V., Berberova N., Gazzaeva R., et al. (2016) Application of new phenolic antioxidants for cryopreservation of sturgeon sperm. Cryobiology 72: 112-118. https://doi.org/10.1016/j. cryobiol.2016.02.006

Osipova V., Kolyada M., Berberova N., et al. (2014) Cryoprotective effect of phosphorous-containing phenolic anti-oxidant for the cryopreservation of beluga sperm. Cryobiology 69: 467-472. https://doi.org/10.1016/j.cryobiol.2014.10.007

Osipova V., Kolyada M., Kudryavtsev K., et al. (2017) Polysubstituted Ionol Derivatives as Inhibitors of Lipid Peroxidation. Russian Journal of General Chemistry 87: 3144-3150. https://doi. org/10.1134/S1070363217130060

Petrosyan V., Milaeva E., Gracheva Yu., et al. (2002) The promoting effect of organotin compounds upon peroxidation of oleic acid. Applied Organometalic Chemistry 16: 655-659. Available at: www.interscience.wiley.com. https://doi.org/10.1002/ aoc.360

Poli G., Leonarduzzi G. and Biasi F. (2004) Oxidative stress and cell signaling. Current Medicinal Chemistry 11: 1163-1182. https://doi.org/10.2174/0929867043365323

Polovinkina M., Osipova V., Kolyada M., et al. (2019) In silico, in vitro, in vivo Evaluation of Antioxidant Activity and Toxic Effects of Phosphorus-Containing Derivatives of 2,6-Di-tert-Butylphenol.
Journal of Environmental Research, Engineering and Management 75(1): 13-23. https://doi.org/10.5755/j01.erem.75.1.21050

Regoli F. and Giuliani M. (2014) Oxidative pathways of chemical toxicity and oxidative stress biomarkers in marine organisms. Marine Environmental Research 93: 106-117. https://doi.org/10.1016/j.marenvres.2013.07.006

Rivera J., Cummings S. and Macys D. (1992) In vitro activation of lipophilic tributyltins by superoxide produces tributylstannyl superoxo radicals, proposed initiators of lipid peroxidation: an EPR model study. Chemical research in toxicology 5: 698-705. https://doi.org/10.1021/tx00029a017

Saïdi S., Azaza M., Windmolders P., et al. (2013) Cytotoxicity evaluation and antioxidant enzyme expression related to heavy metals found in tuna by-products meal: An in vitro study in human and rat liver cell lines. Experimental and Toxicologic Pathology 65: 1025-1033. https://doi.org/10.1016/j.etp.2013.03.001

Shaliutina A., Hulak M., Gazo I., et al. (2013) Effect of short-term storage on quality parameters, DNA integrity, and oxidative stress in Russian (Acipenser gueldenstaedtii) and Siberian (Acipenser baerii) sturgeon sperm. Animal Reproduction Science 139(1-4): 127-135. https://doi.org/10.1016/j.anireprosci.2013.03.006

Shim W., Hong S., Agafonova I., et al. (2006) Comparative Toxicities of Organotin Compounds on Fertilization and Development of Sea Urchin (Anthocidaris crassispina). Bulletin of Environmental Contamination and Toxicology 77: 755-762. https://doi. org/10.1007/s00128-006-1128-2

Tsvetkova L. I. (1997) Methodic Manuals on Sperm Cryoconservation of Carp, Salmon and Sturgeon Fish. VNIIPRKH, Moscow, 11 p.1981

Weber H., Mercord S., Jonas L., et al. (1995) Oxygen radical generation and acute pancreatitis: effects of dibutyltin dichloride / ethanol and ethanol on rat pancreas. Pacreas 11(4): 382-388. https://doi.org/10.1097/00006676-199511000-00010

Перечень рыбохозяйственных нормативов предельно допустимых концентраций (ПДК) и ориентировочно безопасных уровней воздействия (ОБУВ) вредных веществ для воды водных объектов, имеющих рыбохозяйственное значение (The list of fishery standards of maximum permissible concentrations (MPC) and approximately safe exposure levels (TSEL) of harmful substances for water bodies of fisheries importance). М.: «Издво ВНИРО», 1999. 211c.

Tsvetkova L., Savushkina S. and Titareva L., et al. (1997) Meтодическое пособие по криоконсервации спермы карпа, лососевых и осетровых видов рыб (Methodic manuals on sperm cryoconservation of carp, salmon and sturgeon fish). M.: ВНИИРХ. 11c. 